\title{
Irrigation water quality of surface and ground water used for Boro rice cultivation in Khulna district in Bangladesh
}

\author{
M. T. Sultan* and S. M. Billah \\ Soil, Water and Environment Discipline, Khulna University, Khulna-9208, Bangladesh
}

Received: 14 March 2018

Revised: 20 January 2019

Accepted: 06 May 2019

DOI: 10.3329/bjsir.v54i3.42679

\begin{abstract}
Bangladesh is a land of mighty rivers and innumerable tributaries, heavy rainfall and recurring floods. Nearly 75 percent of the country's population depends either directly or indirectly on agriculture. This study deals with the quality of surface and ground water used in rice cultivation of Khulna district, which is located in the south-western part of Bangladesh. This study was carried out to characterize the surface and ground water in terms of different dissolved elements in relation to the suitability of the water for irrigation purposes in Khulna. To analyze the water quality for irrigation of Boro rice, the water samples both surface and ground water were collected from different Upazillas. A reconnaissance survey was conducted in different areas of sampling sites. Collected samples were immediately analyzed for finding important chemical parameters such as $\mathrm{pH}$, Electrical Conductivity (EC),Sodium Adsorption Ratio (SAR), Magnesium Adsorption Ratio (MAR), Soluble Sodium Percentage (SSP), Sodium to Calcium Activity Ratio (SCAR), Sodium Ratio (SR), Residual Sodium Bi-carbonate (RSBC), Kelly's Ratio (KR), Permeability Index (PI) and Total Hardness $\left(\mathrm{H}_{\mathrm{T}}\right)$. From the analysis, it was observed the ionic concentration and other chemical parameters varied in different water sources of the area. SAR, SSP, SCAR and KR are high in all sources where surface water contained most but SR, MAR, $\mathrm{H}_{\mathrm{T}}$ and Permeability were in favorable concentration in both sources in Khulna District. Therefore, the sodicity and alkalinity hazards risk have been found to both of the water sources to use in irrigation purposes.
\end{abstract}

Keywords: Surface and Ground Water; Concentration Level; Irrigation Water Quality

\section{Introduction}

In Bangladesh, optimum use of irrigation water should play an important role in increasing agricultural production. Overall development of the country's agricultural sector will require year round use of irrigation facilities. Irrigation plays a vital role in this country for half of the year (mainly in dry season) when water scarcity seriously handicaps farming operation (Nargis et al., 2009). The rice crop alone occupies 90 - 95 percent of the irrigated area and only 5 10 percent is left for other crops (BBS, 2006). It implies that about $57 \%$ of total cultivable lands are irrigated. Both surface and groundwater is used for the purpose. At present more than $70 \%$ of the irrigated area is served by groundwater and less than $30 \%$ by surface water (Sattar, 2009). Boro rice in Bangladesh of different variety covering more than 4.5 million ha, is entirely irrigated production, mostly with underground water. As a result, besides the increased cost of irrigation, groundwater level is also declining due to excessive withdrawal threatening the environment. Water resources are becoming scarce worldwide. Bangladesh is also no exception. About 60 percent areas are covered by shallow tube-well water for irrigation (BBS, 2006). This resource is not unlimited and in intensive tube well areas water level is declining gradually in each dry season. Irrigated agriculture is dependent on an adequate water supply of usable quality. Quality is defined by certain physical, chemical and biological characteristics. Therefore, some of the important physical and chemical properties of irrigation is necessary to be known to assess its suitability for irrigation (Michael, 1992).Characteristics of irrigation water that define its quality vary with the source of the water. There are regional differences in water characteristics, mainly based on geology and climate. The chemical constituents of irrigation water can affect plant growth directly through

*Corresponding author e-mail: tipu.ku11@gmail.com 
toxicity or deficiency, or indirectly by altering plant availability of nutrients (Ayers and Westcott, 1985). To evaluate the quality of irrigation water, we need to identify the characteristics that are important for plant growth, and their acceptable levels of concentrations.

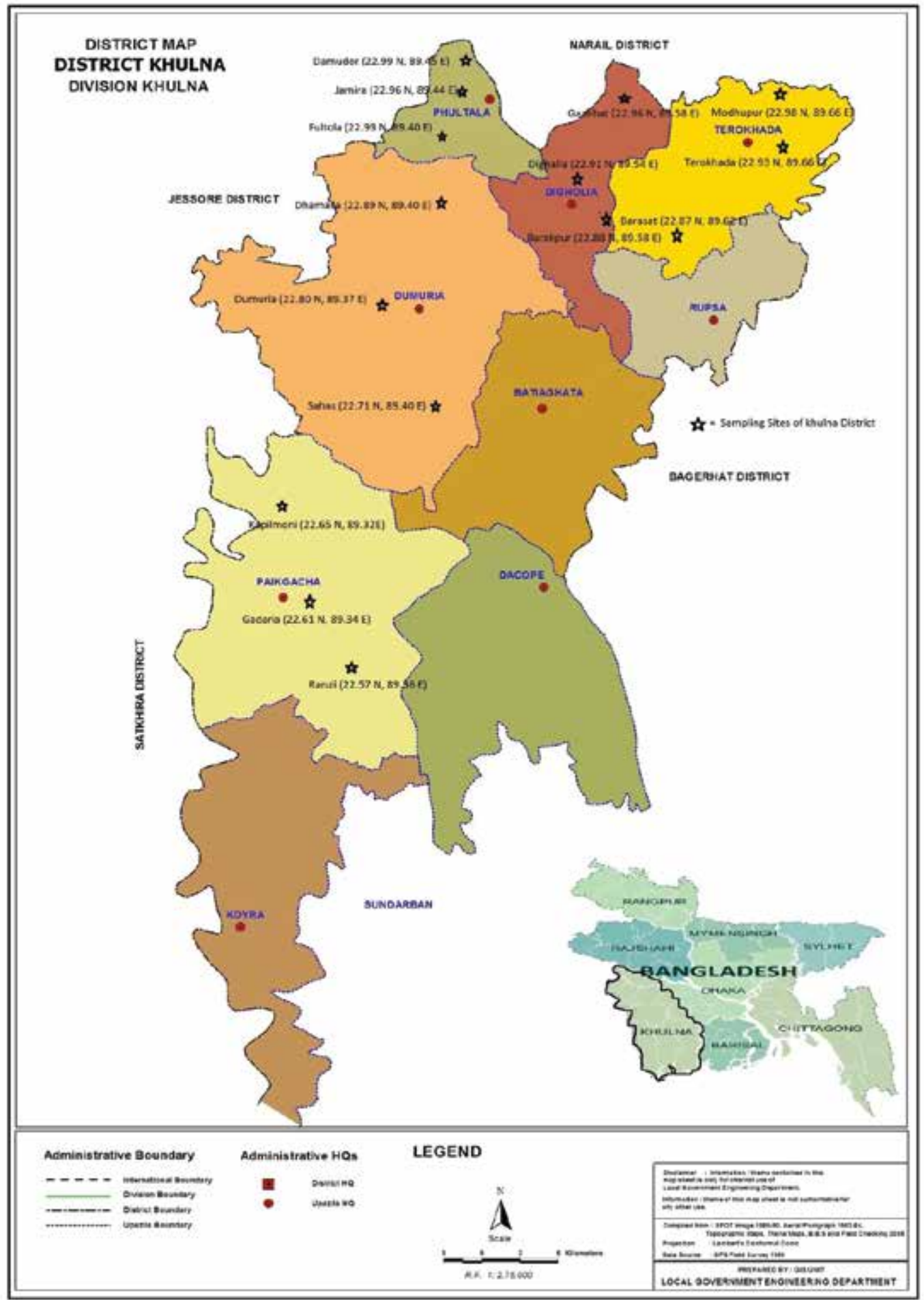

Fig. 1. Map of the sampling sites of Khulna District 


\section{Methodology}

Khulna district is situated in Khulna Division of Bangladesh consisting of 9 Upazilas. It is 4395 square kilometers, located between $21^{\circ} 41^{\prime}$ and $23^{\circ} 00^{\prime}$ North latitude and in between $89^{\circ} 14^{\prime}$ and $89^{\circ} 45^{\prime}$ East longitude. It is 12 feet above from mean sea level (BPC, 2001a). Khulna district is collected from shallow tube-wells; because, maximum farmers use shallow tube-well water for irrigation. Surface water samples were collected from the reservoir beside the crop field which water is used in irrigation purposes. Dry, cleaned and high density PVC bottles without any contamination were used as containers for sampling. This

Table I. Description of sampling sites of Khulna District (BPC, 2001b)

\begin{tabular}{|c|c|c|c|}
\hline $\begin{array}{l}\text { Sampling } \\
\text { Place }\end{array}$ & GPS reading & Major Crops & $\operatorname{Area}\left(\mathrm{Km}^{2}\right)$ \\
\hline Dumuria & $\begin{array}{l}22^{0} 39^{\prime} \text { to } 22^{0} 56^{\prime} \mathrm{N} \\
\text { and } \\
89^{0} 15^{\prime} \text { to } 89^{0} 32^{\prime} \mathrm{E}\end{array}$ & Paddy, Jute, Vegetables etc. & 454.23 \\
\hline Paikgacha & $\begin{array}{l}22^{0} 28^{\prime} \text { to } 22^{0} 43^{\prime} \mathrm{N} \\
\text { and } \\
89^{0} 14^{\prime} \text { to } 89^{0} 28^{\prime} \mathrm{E}\end{array}$ & Paddy, Jute, Vegetables, wheat, pulse, sesame etc. & 411.19 \\
\hline Phultala & $\begin{array}{l}22^{0} 54^{\prime} \text { to } 23^{0} 01^{\prime} \mathrm{N} \\
\text { and } \\
89^{0} 23^{\prime} \text { to } 89^{0} 29^{\prime} \mathrm{E}\end{array}$ & $\begin{array}{l}\text { Paddy, Jute, Vegetables, potato, pulse, turmeric, tobacco } \\
\text { etc. }\end{array}$ & 87.41 \\
\hline Dighalia & $\begin{array}{l}22^{0} 50^{\prime} \text { to } 22^{0} 59^{\prime} \mathrm{N} \\
\text { and } \\
89^{0} 33^{\prime} \text { to } 89^{0} 40^{\prime} \mathrm{E}\end{array}$ & Paddy, Vegetables, wheat, mustard, sesame etc. & 77.17 \\
\hline Terokhada & $\begin{array}{l}22^{0} 50^{\prime} \text { to } 22^{0} 59^{\prime} \mathrm{N} \\
\text { and } \\
89^{0} 34^{\prime} \text { to } 89^{0} 45^{\prime} \mathrm{E}\end{array}$ & Paddy, Coconut, Sugarcane etc. & 189.48 \\
\hline
\end{tabular}

under Ganges River Flood Plain and Gopalganj-Khulna Bills Agro-ecological zone. The physiography is Beel centered. The sampling sites of Khulna District are referred in Fig. 1.

A research was conducted to evaluate the suitability of groundwater and surface water for irrigated agriculture of Khulna District. Hydro-geological studies were carried out on January, 2017. Water (both surface and groundwater) samples were collected and the hydraulic heads were observed at different sampling sites. The sampling sites cover maximum upazilas of Khulna district. A reconnaissance survey was conducted in different areas of sampling sites and the samples were collected from 5 Upazilas among 9 Upazilas of the district. The groundwater samples were field sampling method followed the WHO, UCCC and USEPA system of standard laboratory and field sampling principles, rules and regulations (USEPA, 1976; UCCC, 1974).

The collected water samples were filtered through Whatman no. 42 filter paper $(25 \mu \mathrm{m}$ pore size $)$ before chemical analysis. These were later used for various chemical analyses. $\mathrm{pH}$ was determined electrochemically with the help of glass electrode pH meter as suggested by Jackson (1962). The Electrical Conductivity (EC) of the water samples was 
measured directly by the help of EC meter (USDA, 2004). The available $\mathrm{Na}^{+}$of water samples were determined by a flame analyzer at $767 \mathrm{~nm}$ wavelength (Jackson, 1967). The available $\mathrm{K}^{+}$of water was determined by a flame analyzer at $589 \mathrm{~nm}$ wavelength (Jackson, 1967). The $\mathrm{Ca}^{2+}$ and $\mathrm{Mg}^{2+}$ of water samples were determined by titrimetric method (Lanyon and Heald, 1982). Bicarbonate $\left(\mathrm{HCO}_{3}{ }^{-}\right)$of the water samples were determined by titrimetric method (Jackson, 1962).

Sodium Adsorption Ration (SAR) was determined by the equation using the concentration obtained for $\mathrm{Na}^{+}, \mathrm{Ca}^{2+}$ and $\mathrm{Mg}^{2+}$ of the water samples (Michael, 1992).

$\mathrm{SAR}=\left[\mathrm{Na}^{+}\right] \div\left(\sqrt{1} / 2\left\{\left[\mathrm{Ca}^{2+}\right]+\left[\mathrm{Mg}^{2+}\right]\right\}\right)$. Where, all the ions were expressed in meq $\mathrm{l}^{-1}$.

Magnesium Adsorption Ratio (MAR) was calculated using the $\mathrm{Ca}^{2+}$ and $\mathrm{Mg}^{2+}$ content of the water samples by the equation proposed by Raghunath (1987):

$\mathrm{MAR}=\left\{\mathrm{Mg}^{2+} /\left(\mathrm{Mg}^{2+}+\mathrm{Ca}^{2+}\right)\right\} \times 100$. Where, all the ions were expressed in meq $\mathrm{l}^{-1}$.

Soluble Sodium Percentage (SSP) was calculated using the $\mathrm{Na}^{+}, \mathrm{K}^{+}, \mathrm{Ca}^{2+}$ and $\mathrm{Mg}^{2+}$ content of the water samples by the following equation (Todd, 1980):

$\mathrm{SSP}=\left\{\left(\mathrm{Na}^{+}+\mathrm{K}^{+}\right) /\left(\mathrm{Ca}^{2+}+\mathrm{Mg}^{2+}+\mathrm{Na}^{+}+\mathrm{K}^{+}\right)\right\} \times 100$.

Where, all the ions were expressed in meq $1^{-1}$.

Sodium to Calcium Activity Ratio (SCAR) was calculated using the $\mathrm{Na}^{+}$and $\mathrm{Ca}^{2+}$ concentration of the water samples calculated by the following equation (Gupta and Gupta, 1987):

SCAR $=\mathrm{Na}^{+} / \sqrt{ } \mathrm{Ca}^{2+}$. Where, all the ions were expressed in meq $1^{-1}$.

Sodium Ratio (SR) was calculated using the $\mathrm{Na}^{+}$and $\mathrm{Ca}^{2+}$ content of the water samples calculated by the following equation (NDLI, n.d.):

$$
\begin{gathered}
\mathrm{SR}=\mathrm{Na}^{+} /\left(\mathrm{Na}^{+}+\mathrm{Ca}^{2+}\right) . \text { Where, all the ions were expressed } \\
\text { in meq } l^{-1} .
\end{gathered}
$$

Gupta and Gupta (1987) suggested that alkalinity hazard should be determined through the index called Residual Sodium Bicarbonate (RSBC) to be calculated as:

$$
\mathrm{RSBC}=\mathrm{HCO}_{3}^{-}-\mathrm{Ca}^{2+}
$$

Where, RSBC and the concentration of the constituents were expressed in meq $\mathrm{l}^{-1}$.

The Kelly's Ratio was calculated using the $\mathrm{Na}^{+}, \mathrm{Mg}^{2+}$ and $\mathrm{Ca}^{2+}$ concentration of the samples calculated by the following equation (Kelly, 1963):

$$
\begin{aligned}
\mathrm{KR}= & \left\{\mathrm{Na}^{+} /\left(\mathrm{Mg}^{2+}+\mathrm{Ca}^{2+}\right)\right\} \times 100 . \text { Where, all the ionic } \\
& \text { concentrations were expressed in meq } \mathrm{l}^{-1} .
\end{aligned}
$$

Hardness $\left(\mathrm{H}_{\mathrm{T}}\right)$ is customarily expressed as the equivalent of calcium carbonate (Todd, 1980). Thus:

$\mathrm{H}_{\mathrm{T}}=\left\{\mathrm{Ca}^{2+}\left(\mathrm{mg} \mathrm{l}^{-1}\right)_{2+} \times\right.$ Molecular Weight of $\mathrm{CaCO} /$ Atomic Weight $\mathrm{Ca}\}+\left\{\mathrm{Mg}^{2+}\left(\mathrm{mg} \mathrm{l}^{-1}\right) \times\right.$ Molecular Weight of $\mathrm{CaCO} /$ Atomic Weight $\mathrm{Mg}$ \}.

$$
=\left\{\mathrm{Ca}^{2+}\left(\mathrm{mg} \mathrm{l}^{-1}\right) \times 100.08 / 40.08\right\}+\left\{\mathrm{Mg}^{2+}\left(\mathrm{mg} \mathrm{l}^{-1}\right) \times 100.08\right.
$$

Where, $\mathrm{H}_{\mathrm{T}}, \mathrm{Ca}^{2+}$ and $\mathrm{Mg}^{2+}$ measured in milligram per litter and the ratios are in equivalent weights. Thus the above equation reduced to:

$$
\mathrm{H}_{\mathrm{T}}=2.5 \mathrm{Ca}^{2+}+4.1 \mathrm{Mg}^{2+} \text {. }
$$

The effect on permeability has been evaluated by the term permeability index, which is calculated using the $\mathrm{Na}^{+}, \mathrm{Mg}^{2+}$, $\mathrm{Ca}^{2+}$ and $\mathrm{HCO}_{3}{ }^{-}$concentration of the samples calculated by the following equation (NDLI, n.d.):

$$
\begin{aligned}
\text { Permeability index }= & \left\{\left(\mathrm{Na}^{+}+\sqrt{ } \mathrm{HCO}_{3}\right) /\left(\mathrm{Ca}^{2+}+\mathrm{Mg}^{2+}+\right.\right. \\
& \left.\left.\mathrm{Na}^{+}\right)\right\} \times 100 .
\end{aligned}
$$

Where, ions were expressed as meq $1^{-1}$.

The collected data were compiled and tabulated in proper form and were subjected to statistical analysis. The statistical analyses were carried out by using Computer Programs of Statistical software Minitab (Version 17.0).In statistical analysis, the alphabetic letters (A, B, C...) were used to differentiate the content of elements among the ground water, the alphabetic dash $\left(\mathrm{A}^{\prime}, \mathrm{B}^{\prime}, \mathrm{C}^{\prime} \ldots\right)$ were used to differentiate the content of elements among the surface water and the small letters $(a, b)$ were used to differentiate the content of elements between the ground and surface water samples.

\section{Results and discussion}

Different hydro-chemical properties of irrigation water of Khulna District were compared with the national and international water quality standards set for irrigation. This may be attributed to variations in natural (geochemical) processes and anthropogenic activities within the region. 
Table II. Standard values for irrigation water quality

\begin{tabular}{|c|c|c|}
\hline Parameters & Permissible limit & Reference \\
\hline $\mathrm{pH}$ & $6.5-8.5$ & (Bauderet al., 2011; UCCC, 1974 \\
\hline \multirow[t]{2}{*}{$\mathrm{EC}\left(\mathrm{dS} \mathrm{m} \mathrm{m}^{-1}\right)$} & $<0.7=$ none, $0.7-3.0=$ slight to moderate, $>3.0=$ Severe & UCCC, 1974 \\
\hline & $\begin{array}{l}\text { none }=\leq 0.75, \text { Some }=0.76-1.5, \text { Moderate }=1.51- \\
3.00, \text { Severe }=\geq 3.00\end{array}$ & Bauder et al., 2011 \\
\hline $\operatorname{SAR}\left(\right.$ meq $\left.1^{-1}\right)$ & $\begin{array}{l}1-10=\text { Low } ; 10-18=\text { Medium; } \\
18-26=\text { High }>26=\text { Very High }\end{array}$ & Fipps, 2013 \\
\hline MAR (\%) & $<50$ & Gupta and Gupta, 1987 \\
\hline \multirow[t]{2}{*}{ SSP (\%) } & $<60 \%$ & Khodapanah et al., 2009 \\
\hline & $(40-60) \%$ & Wilcox, 1955 \\
\hline $\operatorname{SCAR}\left(\right.$ meq $\left.1^{-1}\right)$ & $\begin{array}{l}\text { Non-sodic water }<5 \text {, Normal water }=5-10 . \text { Low } \\
\text { water }=10-20, \text { Medium sodicity water }=20-30, \text { High } \\
\text { sodicity water }=30-40 \text {, Very high sodicity water }>40\end{array}$ & Gupta and Gupta, 1987 \\
\hline SR & $<1$ & NDLI, n.d. \\
\hline $\operatorname{RSBC}\left(\right.$ meq $\left.\mathrm{l}^{-1}\right)$ & $\begin{array}{l}\text { Normal water }=0, \text { Low alkalinity water }=2.5 \text {, Medium } \\
\text { alkalinity water }=2.5-5.0, \text { High alkalinity water }=5.0- \\
10.0 \text {, Very high alkalinity water }>10\end{array}$ & Gupta and Gupta, 1987 \\
\hline KR & $<1$ & Kelly, 1963 \\
\hline $\mathrm{H}_{\mathrm{T}}\left(\mathrm{mg} \mathrm{l}^{-1}\right)$ & $>120 \mathrm{mg} \mathrm{l}^{-1}$ & Hem, 1970 \\
\hline PI (\%) & $>65$ & NDLI, n.d. \\
\hline
\end{tabular}

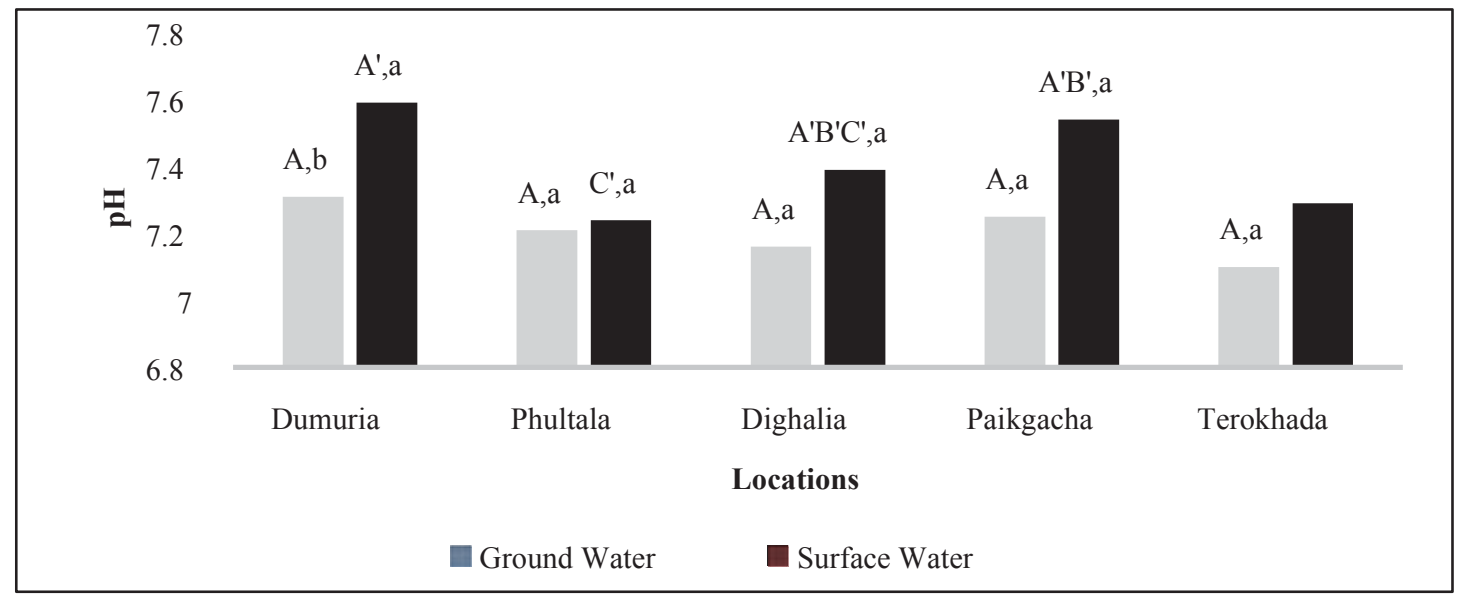

Fig. 2. pH of ground and surface water of different sources in Khulna District 


\section{Acidity $(p H)$}

The $\mathrm{pH}$ of ground water of different sources (Dumuria, Phultala, Dighalia, Paikgacha and Terokhada) of Khulna district were 7.31, 7.21, 7.16, 7.25 and 7.1 respectively. The $\mathrm{pH}$ of surface water of these sources were 7.59, 7.24, 7.39, 7.54 and 7.29 respectively which are presented in Fig.2.

In all cases, the $\mathrm{pH}$ of surface water was higher than that of ground water.From statistical point of view, In Dumuria, the $\mathrm{pH}$ of ground water was significantly $(p \leq 0.05)$ decreased in respect of surface water. In case of ground water, $\mathrm{pH}$ exhibited insignificant difference(at 5\% significance level) among the locations and $\mathrm{pH}$ of surface water in Terokhada and Phultala was significantly $(p \leq 0.05)$ decreased in respect of Dumuria. The $\mathrm{pH}$ of both of ground and surface water are within the permissible limit $(6.5-8.5)$ for irrigation in agriculture (Bauder et al., 2011; UCCC, 1974).
In all cases, the EC of ground water was higher than that of surface water but exhibited insignificant difference(at $5 \%$ significance level). EC of ground water exhibited insignificant difference (at 5\% significance level) among the locations and the EC of surface water of Dighalia and Terokhada was significantly $(p \leq 0.05)$ decreased in respect of Dumuria.The EC of ground water is moderately limited for irrigated agriculture (Bauderet al., 2011) and slight to moderate $(0.7-3)$ restriction for irrigation use (UCCC, 1974). The EC of surface water is limited in some extent for irrigated agriculture and can be used for irrigation purposes with some management practices (Bauderet al., 2011, UCCC, 1974).

\section{Sodium adsorption ratio (SAR)}

Sodium Adsorption Ratio (SAR)of ground water of different sources (Dumuria, Phultala, Dighalia, Paikgacha and Terokhada) of Khulna district were 10.87, 18.61, 8.99, 3.04

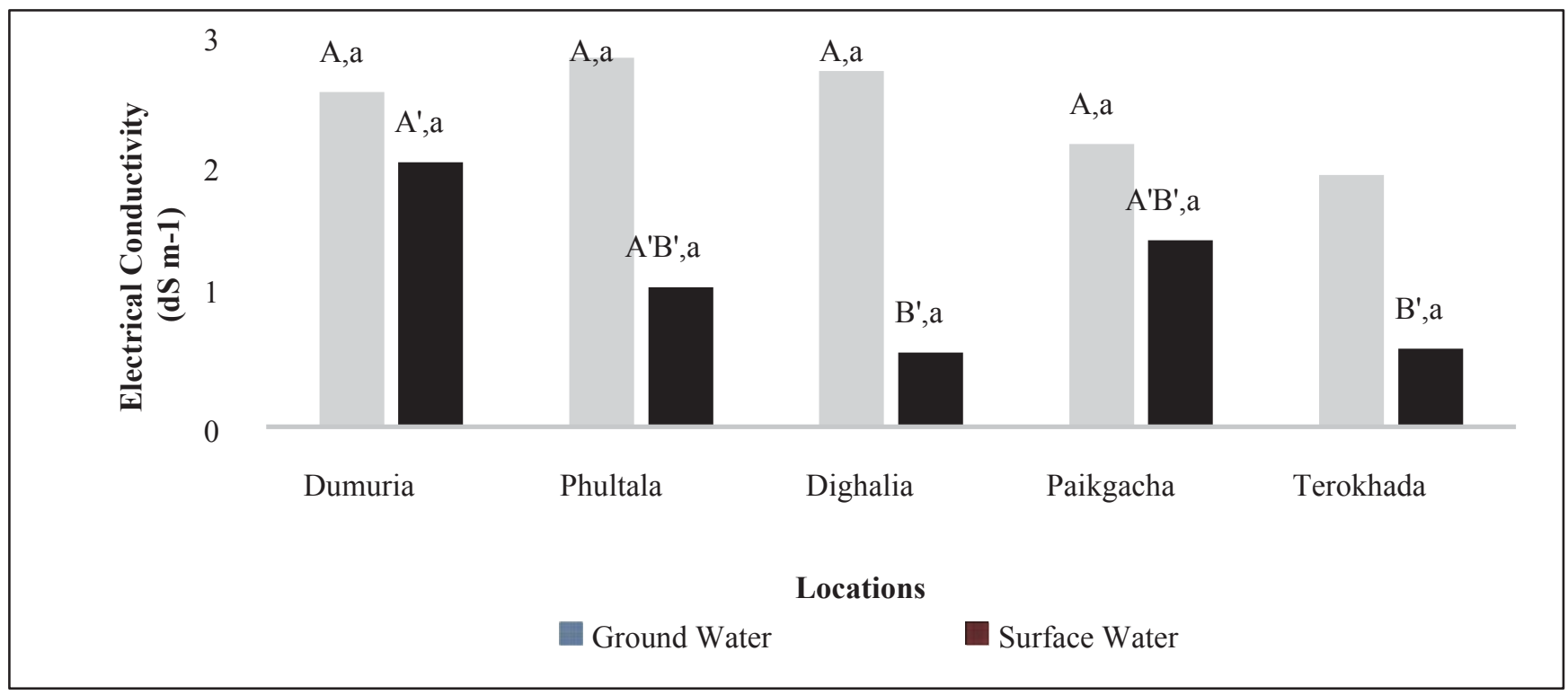

Fig. 3. EC of ground and surface water of different sources of Khulna District

\section{Electrical conductivity (EC)}

The Electrical Conductivity (EC) of ground water of different sources (Dumuria, Phultala, Dighalia, Paikgacha and Terokhada) of Khulna district were $2.57 \mathrm{dS} \mathrm{m}^{-1}, 2.83 \mathrm{dS} \mathrm{m}^{-1}$, $2.73 \mathrm{dS} \mathrm{m}^{-1}, 2.17 \mathrm{dS} \mathrm{m}^{-1}$ and $1.93 \mathrm{dS} \mathrm{m}^{-1}$ respectively. The EC of surface water of these sources were $2.03 \mathrm{dS} \mathrm{m}^{-1}, 1.07 \mathrm{dS}$ $\mathrm{m}^{-1}, 0.57 \mathrm{dS} \mathrm{m}^{-1}, 1.43 \mathrm{dS} \mathrm{m}^{-1}$ and $0.6 \mathrm{dS} \mathrm{m}^{-1}$ respectively which are presented in Fig. 3. and $6.72 \mathrm{meq} 1^{-1}$ respectively. The SAR of surface water of

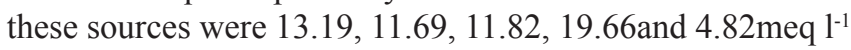
respectively which are presented in Fig. 4.

SAR of surface water was higher than that of ground water in Dumuria, Dighalia and Paikgacha and the reverse condition was in Phultala and Terokhada but statistically exhibited insignificant difference (at 5\% significance level) between ground and surface water. SAR of ground water of Phultala was significantly $(p \leq 0.05)$ increased in respect of 


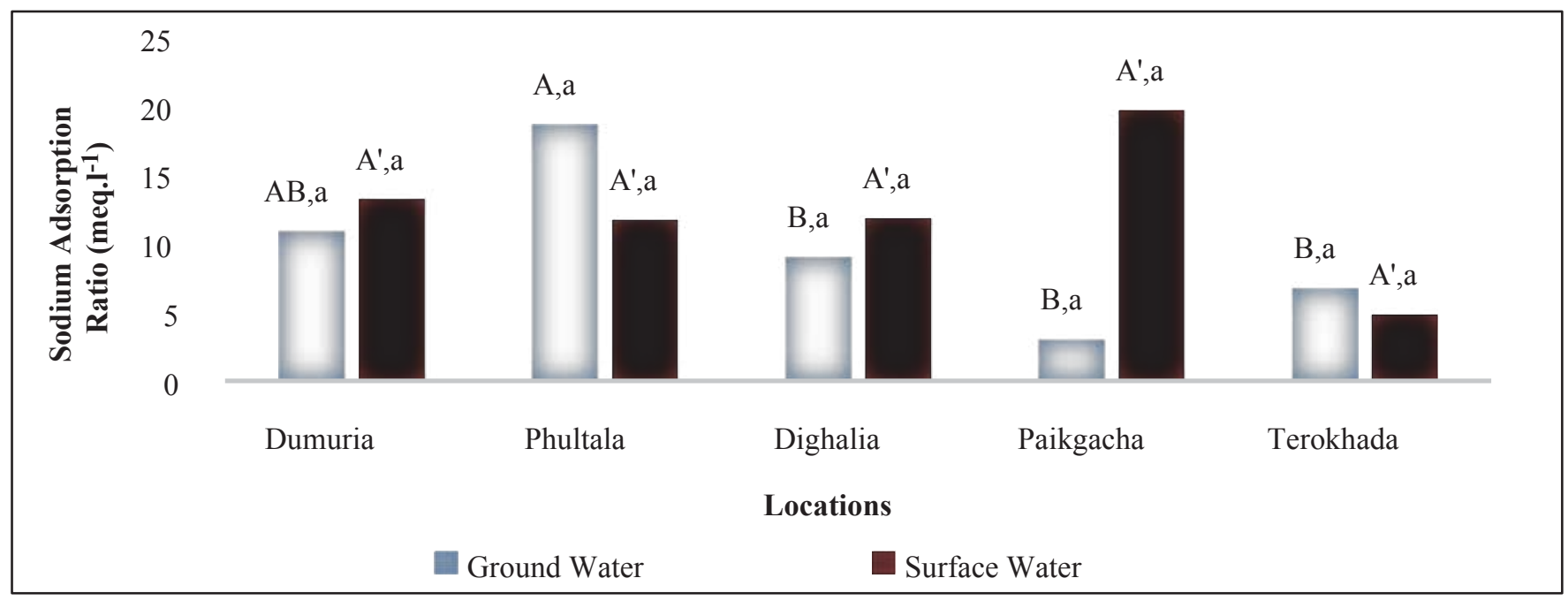

Fig. 4. SAR of ground and surface water of different sources in Khulna

Paikgacha, Dighalia and Terokhada but The SAR of surface water showed variable behavior among different locations of Khulna district, but surface water samples exhibited insignificant difference (at 5\% significance level) among the locations.The ground water of Dighalia, Paikgacha and Terokhada as well as the surface water of Terokhada had slight to moderate restriction to use as irrigation and rest of all were severe (UCCC, 1974). Based on SAR, ground water of Paikgacha was in 'Fair class', samples of Terokhada were in 'Poor class' and rest of all were in 'Very poor class' (Moss and Kress, 2013). According to Fipps (2013), the ground water of Dighalia, Paikgacha and Terokhada as well as the surface water of Terokhada showed low (1 - 10); ground water of Phultala and surface water of Paikgacha had high $(18-26)$ and rest of all had medium $(10-18)$ Sodium hazard. The combining effect of average EC and SAR of ground water showed slight to moderate where the surface water showed severe restriction of use for irrigation (UCCC, 1974).

\section{Magnesium adsorption ratio (MAR)}

Magnesium Adsorption Ratio (MAR) of ground water of different sources (Dumuria, Phultala, Dighalia, Paikgacha and Terokhada) of Khulna district were $27.7 \%, 37.52 \%, 20.39 \%$, $25.88 \%$ and $18.21 \%$ respectively. The MARof surface water of these sources were $45.8 \%, 29.18 \%, 22.59 \%, 13.33 \%$ and $16.33 \%$ respectively which are presented in Fig. 5.

MAR of ground water was higher than that of surface water in Phultala, Paikgacha and Terokhada but the reverse condition was in Dumuria and Dighalia. Statistically, the MAR of ground water exhibited insignificant difference (at 5\% significance level) in respect of surface water in all sources of water. MAR of ground water exhibited insignificant difference (at 5\% significance level) with among the locations but in surface water, the MAR of Paikgacha and Terokhada was significantly $(p \leq 0.05)$ decreased in respect of Dumuria. As, both of ground and surface water had the MAR below 50, all the sources are suitable to use in irrigation purposes (Gupta and Gupta, 1987).

\section{Soluble sodium percentage (SSP)}

Soluble Sodium Percentage (SSP) of ground water of different sources (Dumuria, Phultala, Dighalia, Paikgacha and Terokhada) of Khulna district were $67.82 \%, 80.62 \%, 60.19 \%$, $41.15 \%$ and $62.8 \%$ respectively. The SSPof surface water of these sources were $76.57 \%, 79.07 \%, 75.25 \%, 79.46 \%$ and $63.38 \%$ respectively which are presented in Fig. 6 .

The SSP of surface water was higher than that of ground water in all locations except Phultala (Fig. 6). The SSP of ground water of Paikgacha was significantly $(p \leq 0.05)$ decreased in respect of surface water.In case of ground water, SSP of Phultala was significantly $(p \leq 0.05)$ increased and Paikgacha was decreased in respect of Dumuria, Dighalia and Terokhada. But, the SSP of surface water exhibited insignificant difference (at 5\% significance level) among the locations.All of the sources of water contain high SSP (> $60 \%$ ) except the ground water of Paikgacha which may indicate high sodicity that can break down the soil physical structure (Khodapanah et al., 2009). The ground water of Paikgacha fell under 'Fair class' and others under 'Very poor class' (Wilcox, 1955).

\section{Sodium to Calcium activity Ratio (SCAR)}

The Sodium to Calcium Activity Ratio (SCAR) of ground water of different sources (Dumuria, Phultala, Dighalia, 


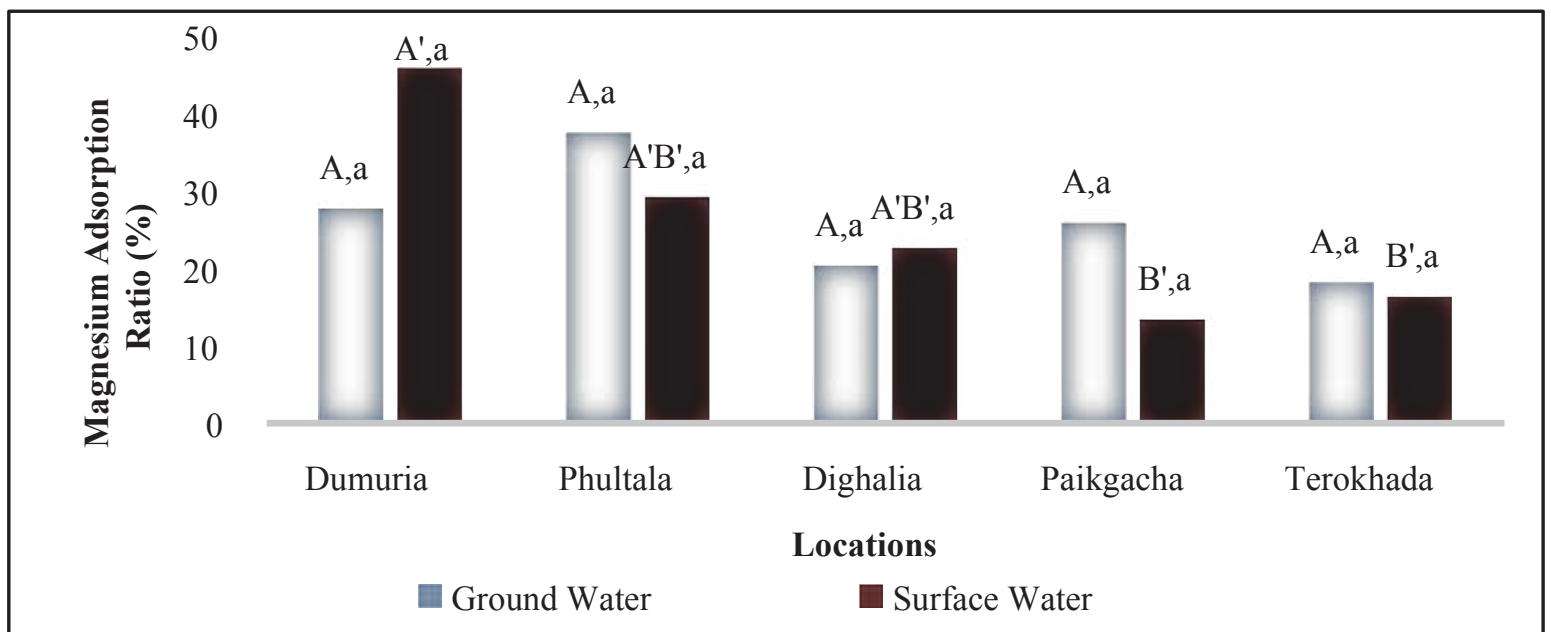

Fig. 5. MAR of ground and surface water of different sources in Khulna

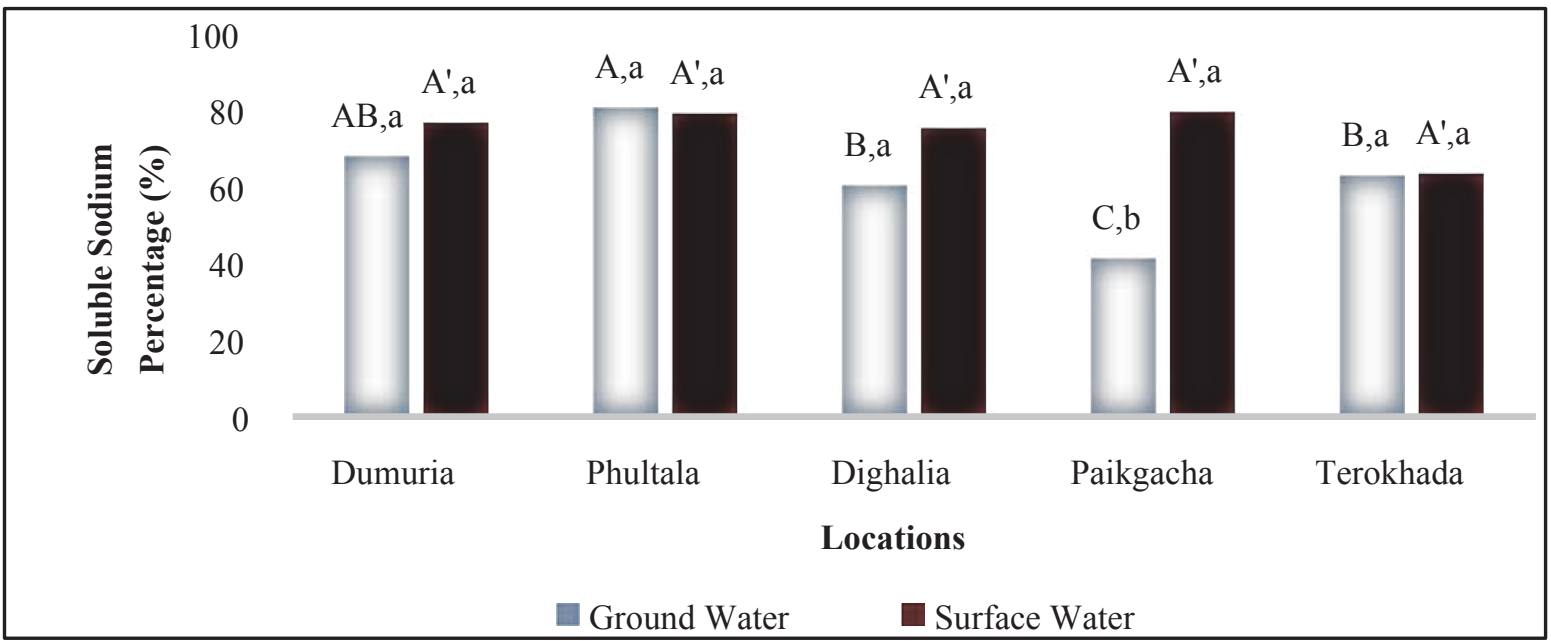

Fig. 6. SSP of ground and surface water of different sources in Khulna

Paikgacha and Terokhada) of Khulna district were 9.39, $16.52,6.88,2.52$ and $4.3 \mathrm{meq}^{-1}$ respectively. The SCAR of surface water of these sources were 14.36, 9.86, 4.06, 12.3 and $10.62 \mathrm{meq}^{-1}$ respectively which are presented in Fig. 7.

The SCAR of surface water was higher than that of ground water in all locations except Phultala and Dighalia. The SCAR of ground water of Phultala was significantly ( $p \leq$ $0.05)$ increased in respect of surface water. SCAR of ground water of Phultala was significantly $(p \leq 0.05)$ increased and Paikgacha was decreased in respect of Dumuria, Dighalia and Terokhada. On the other hand, the SCAR of surface water exhibited insignificant difference (at 5\% significance level) among the locations. According to the classification of Gupta and Gupta (1987), the ground water of Paikgacha and Terokhada as well as the surface water of Dighalia are
'Non-sodic' (SCAR ratio < 5); the ground water of Dumuria and Dighalia as well as surface water of Phultala are 'Normal' (SCAR ratio = 5 - 10); the ground water of Phultala as well as the surface water of Dumuria, Paikgacha and Terokhada are 'Low sodic water' $($ SCAR ratio $=10-20)$.

\section{Sodium ratio (SR)}

The Sodium Ratio (SR) of ground water of different sources (Dumuria, Phultala, Dighalia, Paikgacha and Terokhada) of Khulna district were $0.74,0.87,0.65,0.49$ and 0.58 respectively. The SR of surface water of these sources were $0.85,0.84,0.78,0.78$ and 0.73 respectively which are presented in Fig. 8. 


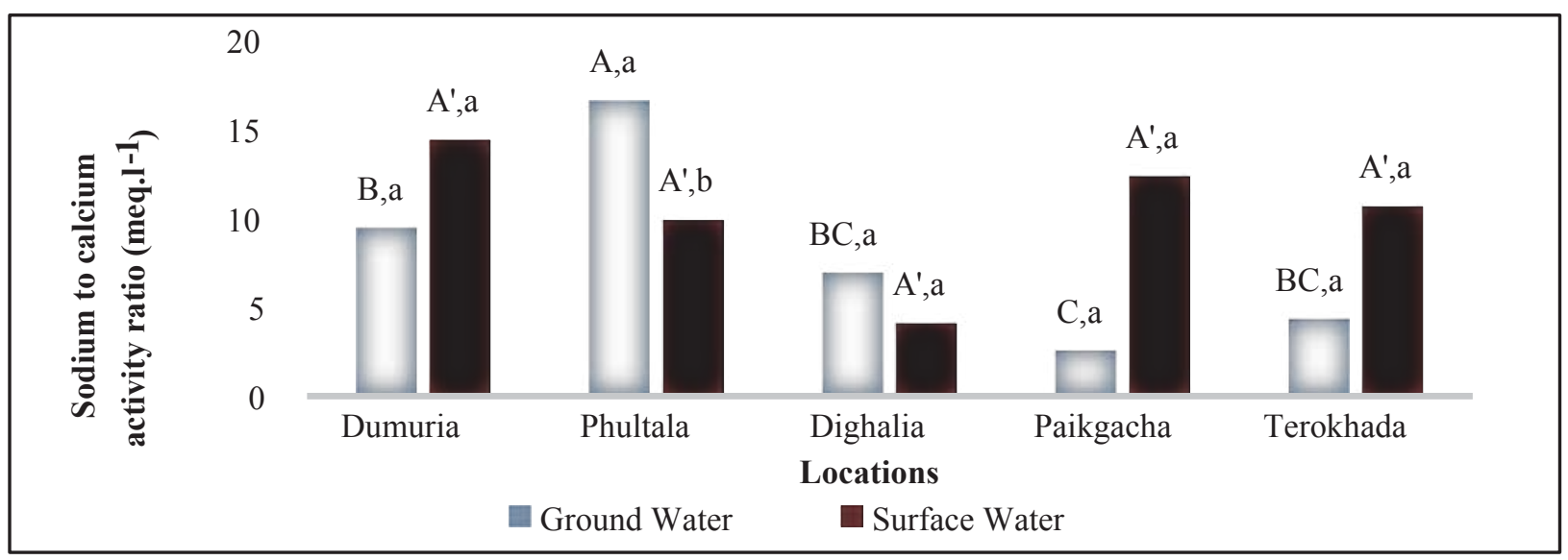

Fig. 7. SCAR of ground and surface waterof different sources in Khulna

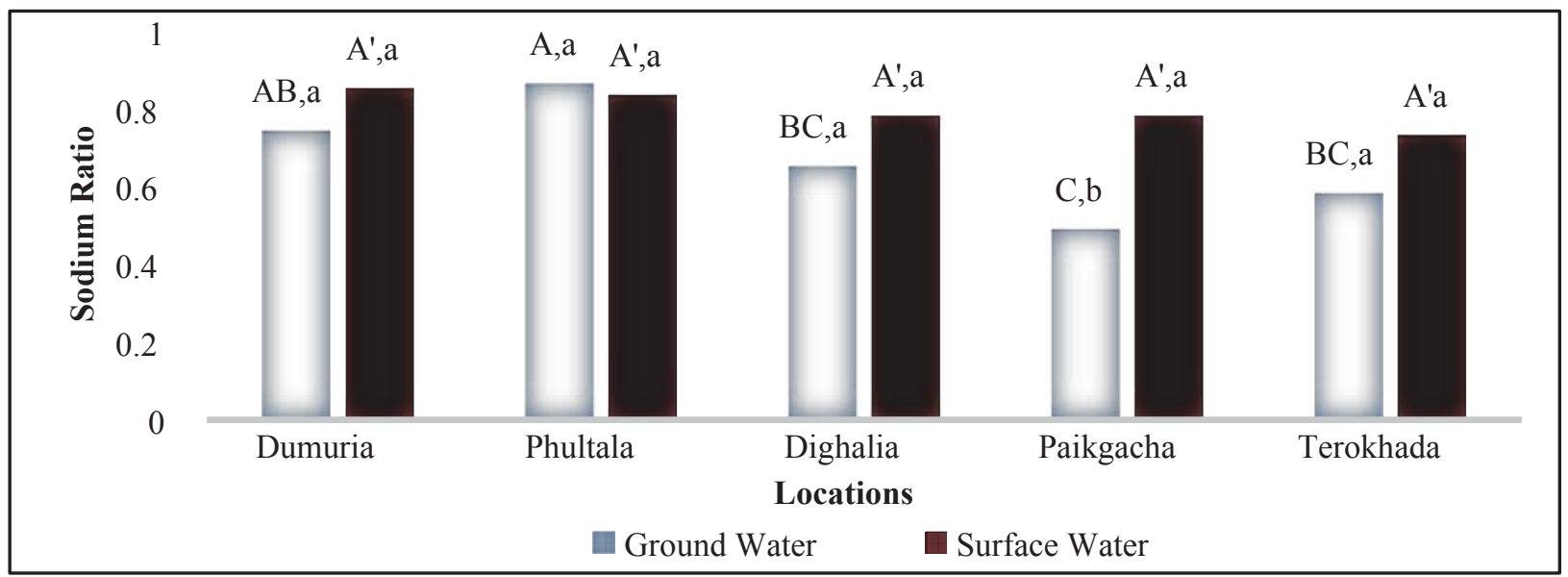

Fig. 8. SR of ground and surface water of different sources in Khulna

The SR of surface water was higher than that of ground water in all the locations except Phultala. The SR of ground water was significantly $(p \leq 0.05)$ decreased in respect of surface water in Paikgacha. Statistically, the SR of ground water of Phultala was significantly $(p \leq 0.05)$ increased and Paikgacha was decreased in respect of Dumuria, Dighalia and Terokhada. But, the SR of surface water exhibited insignificant difference (at 5\% significance level) among the locations. All the SR of both of surface and ground water are good $(\mathrm{SR}<1)$ for irrigation purposes (NDLI, n.d.). As, the SR of ground water is low than surface water (except Phultala) is preferable to use for irrigation.

\section{Residual sodium bicarbonate (RSBC)}

The residual sodium Bi-carbonate (RSBC) of ground water of different sources (Dumuria, Phultala, Dighalia, Paikgacha and Terokhada) of Khulna district were 28.6, 41.2, 29.6, 20.37 and 26.13 meq $^{-1}$ respectively. The RSBC of surface water of these sources were 15.8, 18.4, 15.47, 22 and 19.87 meq $1^{-1}$ respectively which are presented in Fig. 9.

RSBC of ground water was higher than that of surface water in all the locations except Paikgacha. The RSBC of ground water was significantly $(p \leq 0.05)$ increased in respect of surface water in Phultala and Dighalia. RSBC of ground water of Phultala was significantly $(p \leq 0.05)$ increased in respect of Dumuria, Paikgacha and Terokhada. On the other hand, the RSBC of surface water exhibited insignificant difference (at 5\% significance level) among the locations. The $\mathrm{RSBC}$ of both of ground and surface water was high due to the high content of $\mathrm{HCO}_{3}^{-}$of the sources. All the samples both of ground and surface water are very high alkaline water $\left(>10\right.$ meq $^{-1}$ ) and plants suffer with alkaline hazard by using as irrigation (Gupta and Gupta, 1987). 


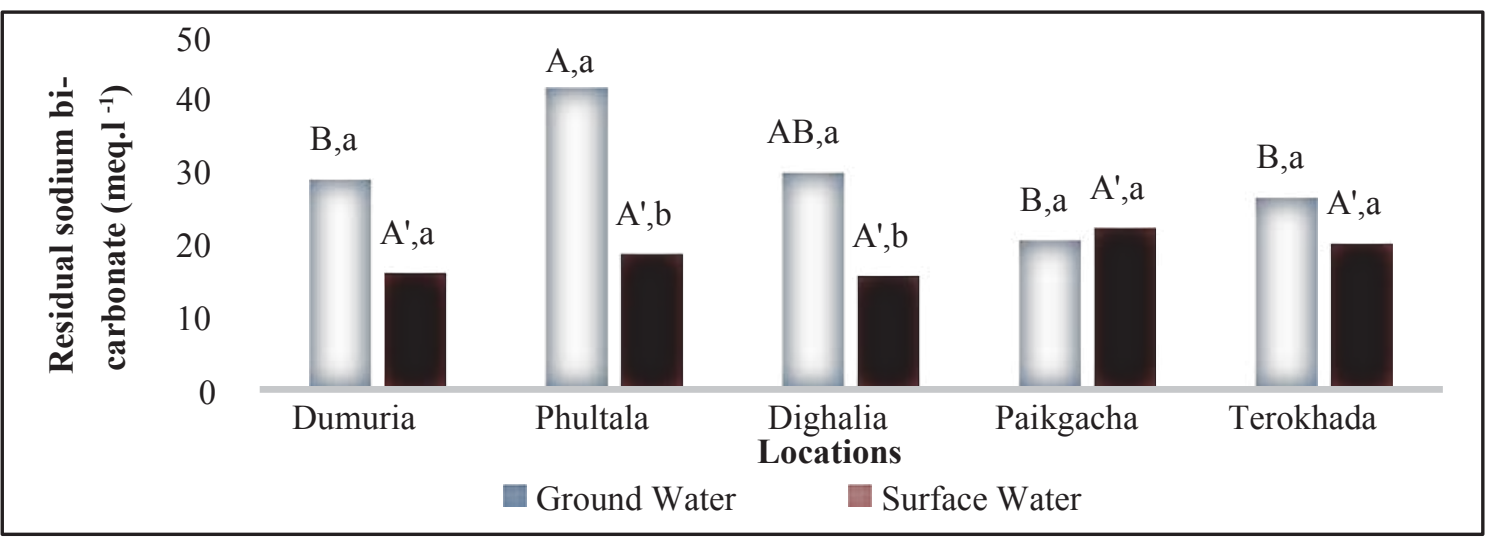

Fig. 9. RSBC of ground and surface water of different sources in Khulna

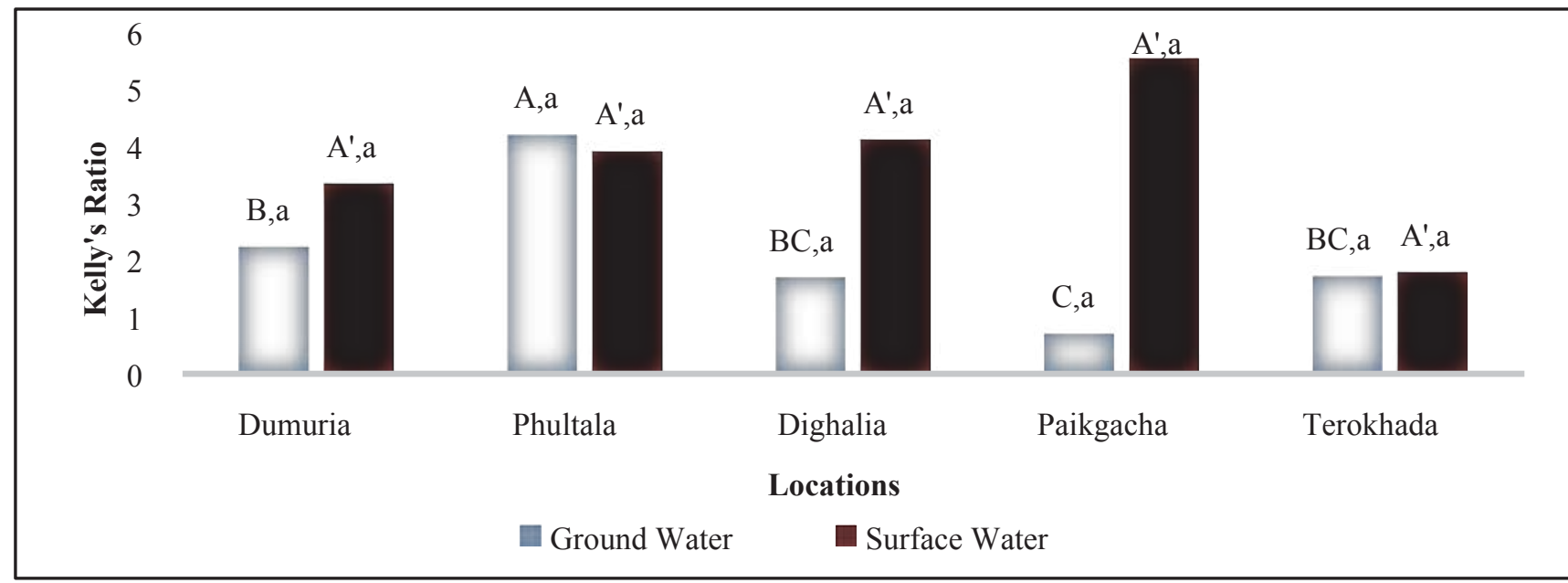

Fig. 10. KR of ground and surface water of different sources in Khulna

\section{Kelly's ratio $(K R)$}

The Kelly's Ratio (KR) of ground water of different sources (Dumuria, Phultala, Dighalia, Paikgacha and Terokhada) of Khulna district were 2.22, 4.184, 1.679, 0.6933 and 1.7 respectively. The KR of surface water of these sources were $3.33,3.902,4.1033,5.53$ and 1.776 respectively which are presented in Fig. 10.

The KR of surface water was higher than that of ground water in all the locations except Phultala. The KR of ground water exhibited insignificant difference (at 5\% significance level) in respect of surface water of all the locations. Statistically, the KR of ground water of Phultala was significantly $(p \leq 0.05)$ increased and Paikgacha was decreased in respect of Dumuria, Dighalia and Terokhada. On the other hand, the KR of surface water exhibited insignificant difference (at 5\% significance level) among the locations. Among the ground water sources, Among the ground water sources, Paikgacha showed suitability $(\mathrm{KR}<1)$ for irrigation and Phultala showed unsuitability $(\mathrm{KR}>3)$; others were in the between ranges (Kelly, 1963). Among the surface water sources all but Terokhada showed unsuitability (KR > 3) for irrigation (Kelly, 1963). So, it can be concluded that, most of the water resources are more subjected to Sodium hazard in the study area (Shammi et al., 2016).

\section{Total Hardness $\left(H_{T}\right)$}

The Total Hardness $\left(\mathrm{H}_{\mathrm{T}}\right)$ of ground water of different sources (Dumuria, Phultala, Dighalia, Paikgacha and Terokhada) of Khulna district were 600.13, 534, 615.12, 484 and $429 \mathrm{mg} \mathrm{l}^{1-1}$ respectively. The $\mathrm{H}_{\mathrm{T}}$ of surface water of these sources were 403.52, 228.9, 189.25, 316.55 and $208.9 \mathrm{mg} \mathrm{l}^{-1}$ respectively which are presented in Fig. 11.

$\mathrm{H}_{\mathrm{T}}$ of ground water was higher than that of surface water in all the locations but exhibited insignificant difference (at 5\% 


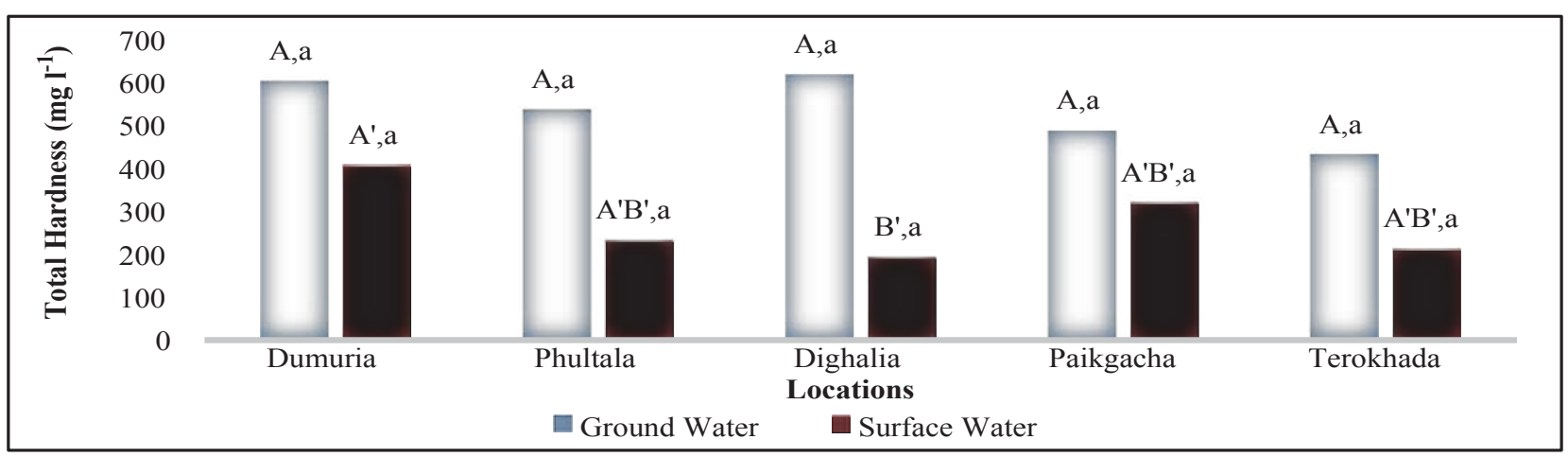

Fig. 11. $H_{T}$ of ground and surface water of different sources in Khulna

significance level). $\mathrm{H}_{\mathrm{T}}$ of ground water exhibited insignificant difference (at 5\% significance level) among the locations but, $\mathrm{H}_{\mathrm{T}}$ of surface water of Dighalia was significantly $(p \leq 0.05)$ decreased in respect of Dumuria and other sources exhibited insignificant difference. The high value $\left(>120 \mathrm{mg} \mathrm{l}^{-1}\right)$ of $\mathrm{H}_{\mathrm{T}}$ in both of ground and surface water indicates hard water (Hem, 1970). According to the Total Hardness classification (Sawyer and McCarty, 1967), the surface water and the ground water of the study area is very hard (150-300 $\left.\mathrm{mg} \mathrm{l}^{-1}\right)$. The ground water quality beyond the permissible limit, however surface water fulfills the requirement of irrigation water quality in case of total hardness by DoE (1997).
Phultala was significantly $(p \leq 0.05)$ increased in respect of Paikgacha and other sources exhibited insignificantly difference but, surface water exhibited insignificant difference (at 5\% significance level) among the locations. The PI of both of ground and surface water was high due to the high content of $\mathrm{HCO}_{3}^{-}$and $\mathrm{Na}^{+}$of the sources. All the samples both of ground and surface water are suitable for irrigation as its value exceeds 65 (NDLI, n.d.).

\section{conclusion}

EC prevailed in ground water than surface water where $\mathrm{pH}$ was within permissible limit to both of ground and surface

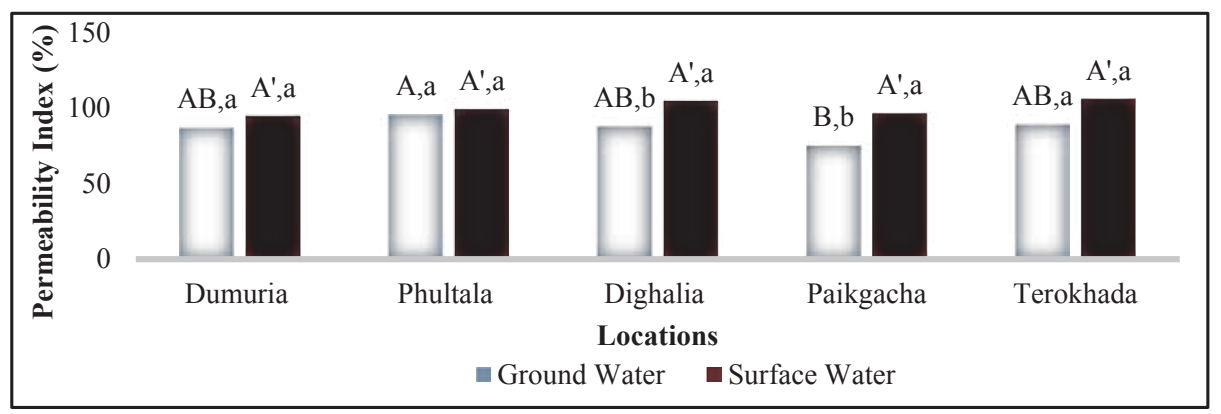

Fig. 12. PI of ground and surface water of different sources in Khulna

Permeability Index (PI)

The Permeability Index (PI)of ground water of different sources (Dumuria, Phultala, Dighalia, Paikgacha and Terokhada) of Khulna district were $87.29 \%, 95.71 \%, 88.10 \%$, $75.52 \%$ and $89.44 \%$ respectively. The PIof surface water of these sources were $94.68 \%, 99.48 \%, 104.93 \%, 96.63 \%$ and $106.01 \%$ respectively which are presented in Fig. 12.

The PI of surface water was higher than that of ground water in all locations and statistically, the PI of ground water was significantly $(p \leq 0.05)$ decreased in respect of surface water in Paikgacha and Dighalia. The PI of ground water of water. $\mathrm{EC}$ and $\mathrm{H}_{\mathrm{T}}$ of collected surface water samples was excellent but ground water had slight to moderate restriction to use for irrigation.SAR, SSP, SCAR and KR were high in all sources but surface water contained more than ground. No SR, MAR, and Permeability problem was found to exist in Khulna District. Therefore, it can be concluded that, all the sources of surface water and ground water has the risk of sodicity hazard as well as alkali hazard for irrigation that should be treated properly to use. Preferably, ground water is easier to treat as containing lesser problems. But, if possible, the surface water should use for irrigation with proper treatment to lessen the pressure on ground water reservoir. 


\section{References}

Ayers RS and Westcott DW (1985), Water Quality for Agriculture, Irrigation and Drainage Ed. UN Food and Agriculture Organization, Rome 29(1): 1-117.

Bauder TA, Waskom RM, Sutherland PL and Davis JG (2011), Irrigation Water Quality Criteria. Fact Sheet No. 0.506.

BBS (Bangladesh Bureau of Statistics) (2006), Statistical Yearbook of Bangladesh, Statistics Division, Ministry of Planning, Government of the People's Republic of Bangladesh, Dhaka.

BPC (Bangladesh Population Census) (2001a), Bangladesh Bureau of Statistics: Cultural survey report of Khulna District, 2007.

BPC (Bangladesh Population Census) (2001b), Bangladesh Bureau of Statistics. Cultural survey report upazilas of Khulna District, 2007.

DoE (Department of Environment) (1997), The Environment Conservation Rules 1997. Bangladesh Gazette no. DA-1, Ministry of Environment and Forest, Dhaka, Bangladesh, pp 1324-1327.

Fipps G (2013), Irrigation Water Quality Standards and Salinity Management Strategies. A and M Agrilife Extension Service. Texas, USA.

Gupta SK and Gupta IC (1987), Management of Saline Soils and Water. Oxford and IBH publication Company. New Delhi, India, p 399.

Hem JD (1970), Study and Interpretation of the Chemical Characteristics of Natural Water. United States Geological Survey. WSP 1473, Washington, DC, p 363.

Jackson ML (1962), Soil Chemical Analysis, Prentice Hall, Inc., Englewood cliffs, New Jersey, USA.

Jackson ML (1967), Soil Chemical Analysis, Prentice Hall of India Private Limited. New Delhi, p 498.

Kelly WP (1963), Use of Saline Irrigation Water. Soil Science 95(4): 355-391.

Khodapanah L, Sulaiman WNA and Khodapanah N (2009), Groundwater Quality Assessment for Different Purposes in Eshtehard District. European Journal of Scientific Research, Tehran, Iran 36(4): 543-553.

Lanyon LE and Heald WR(1982), Magnesium, Calcium, Strontium and Barium In: Methods of soil analysis. Part II. $2^{\text {nd }}$ Ed., Agronomy. American Society of Agronomy, Inc., Madison, Wisconsin, USA 09: 252-255.
Michael AM (1992), Irrigation Theory and Practices. Vikas Publishing House Limited, New Delhi, India, p 740.

Moss J and Kress M (2013), Turf Irrigation Water Quality: A Concise Guide, Division of Agricultural Sciences and Natural Resources, Oklahoma State University, Oklahoma, USA.

Nargis F, Miah TH, Khanam TS and Sarwer RH (2009), Profitability of mv Bororice production under shallow tubewell irrigation system in some selected areas of tangail district, Department of Agricultural Economics, Bangladesh Agricultural University Mymensingh-2202, Bangladesh 20(1\&2): 237-244.

NDLI (National Digital library of India) Soil Science and Agricultural Chemistry. Lecture: 27: Assessment of irrigation water quality. Tamil Nadu Agricultural University, India.

Raghunath IIM (1987), Groundwater. $2^{\text {nd }}$ Ed., Wiley Eastern Ltd., New Delhi, India.

Sattar MA (2009), Cost effective, environment friendly Boro rice cultivation, IWM Division, BRRI, Gazipur.

Sawyer CN and McCarty PL (1967), Chemistry for Sanitary Engineers, and classification of naturally soft and naturally hard waters to sources and hardness of their water supplies, Journal of Hydrology, New York, U.S.A.

Shammi M, Karmakar B, Rahman MM, Islam MS, Rahman R and Uddin MK (2016), Assessment of Salinity Hazard of Irrigation Water Quality in Monsoon Season of Batiaghata Upazila, Khulna District, Bangladesh and Adaptation Strategy. Pollution 2(2): 183-197.

Todd DK (1980), Groundwater Hydrology, Wiley International Edition, John Wiley and Sons, Inc., NY, UK.

UCCC (University of California Committee of Consultants) (1974) Guidelines for interpretation of water quality for irrigation. Technical Bulletin, University of California committee of consultants, California, USA, pp 20-28.

USDA (United States Department of Agriculture) (2004), Soil survey laboratory manual. soil survey investigation report no. 42, version 4.0, USDA-NRCS, Nebraska, USA.

USEPA (United States Environmental Protection Agency) (1976), Quality Criteria for Water, EPA-440/9-76-023.

Wilcox LV (1955), Classification and use of irrigation waters. US Department of Agriculture, Circular 969, Washington, D.C., USA, p 19. 